\title{
Analysis of Stability and Exposure of Croatian Bank System to Non-Credit Risks
}

\author{
Zoran Wittine, $\mathrm{PhD}$ (Corresponding author) \\ Dept. of International Economics, Faculty of Economics and Business \\ University of Zagreb, Trg J. F. Kennedy 6, Zagreb, Croatia \\ Tel: 385-1238-3350 E-mail: zwittine@efzg.hr
}

Ivana Vuk

Faculty of Economics and Business, University of Zagreb

Tomislavova 7, Križevci, Croatia

Tel: 385-958-645-334Ｅ-mail: ivanavuk8@gmail.com

Received: June 7, 2016 Accepted: July 6, 2016

doi:10.5296/ber.v6i2.10211ＵRL: http://dx.doi.org/10.5296/ber.v6i2.10211

\begin{abstract}
Paper focuses on Croatian banking sector and looks into factors that affect its stability. It analyses resilience of the banking sector to external shocks, determines factors of risk resilience and relates them to present situation in Croatia. Finally, it discusses results of stress testing conducted by Croatian National Bank and draws conclusions pertaining to Croatian financial sector.
\end{abstract}

Keywords: Croatia, Risk, Resilience, Bank system stability

\section{Introduction}

Stability of the banking sector is extremely important for every economy. Recent and somewhat further past witnesses it. The instability of the banking sector can easily undermine the strength of any economy and through diminished confidence of private and corporate entities deepen the effects of potential crisis even further. The stability of the banking system, therefore, is today a sine qua non condition for a healthy economy. Of particular importance for achieving business success to banks are credit risks which are thus logically in the focus of most professional and scientific researches dealing with banks and banking systems. In most countries, market regulators force banks to closely monitor and control their exposure to 
credit risks which is one of the reasons why banks have introduced advanced systems to monitor such risks. However, excessive focus on credit risk management can result in loss of sight of other business risks that may significantly determine the success of the bank. Due to the complexity of today's environment, and constantly-changing internal and external factors, non-credit risks play an increasingly important role in the value creation chain of banks, primarily market and operational risks.

This paper will deal with stability of Croatian banking system as well as its resilience to external shocks. In that regard, authors will provide insight into the structure of Croatian banking system, as well as structure of bank's assets and liabilities. Furthermore, authors will address key indicators of banking system stability, determine factors of risk resilience and relate them to the current situation in Croatia. In the end, authors will analyze results of recent stress testing and discuss implications of it.

\section{Literature Review}

Aftermath of recent financial crisis has given incentive for research into bank system stability and stress testing practices all over the world. In order to avoid future repetition of similar crisis, regulators acknowledged banks need to be more resilient to external shocks. In order to gain useful insights into the matter, many scientific research have been conducted, some trying to identify crucial factors which undermine bank system stability, while others tried to assess strengths and weaknesses of current stress testing practices and/or recommend how to re-design the very stress testing process.

Vallascas and Keasey (2012) explored bank resilience to systemic shocks and stability of banking systems. They showed that restrictions on a bank's leverage ratio and the imposition of liquidity requirements may improve the resilience of a bank to systemic events and that bank size, the share of non-interest income and asset growth are key determinants of a bank's risk exposure. Their research also showed that the strengthening of individual bank stability obtained via size restrictions is accompanied by a reduction of the contribution to systemic risk for banks which are relatively large compared to the domestic economy.

Melecky and Podpiera (2012) and later Hristev (2014) examined stress-test practices of central banks from Central, Eastern and Southeastern European (CESEE) countries. They outlined lessons for the main components of the macroprudential stress-test process and showed that there is no universal way for carrying out stress testing because the very process is dependent on many country specific variables. Similar research has been conducted by Geršl et al. (2013) with the difference it focused on only one Central European Country, namely Czech Republic.

Singh and Majumdar (2013) investigated how changes in macroeconomic conditions affect bank resilience. In that regard they carried out macro stress testing using Vector Autoregressive (VAR) approach and found out macroeconomic variables had significant impact on banks' stability.

Schuermann (2014) investigated stress testing itself trying to answer why it is useful and why it has become such a popular tool for the regulatory community in the course of the recent 


\section{Al Macrothink}

Business and Economic Research

ISSN 2162-4860

2016, Vol. 6, No. 2

financial crisis, at the same time trying to answer how stress testing should be done and whether it should be different in crisis vs. non-crisis times.

Hu et al. (2014) spurred by weaknesses of current stress testing (i.e. lack of effective methods for modeling and analyzing "exceptional but plausible" risk scenarios in banks) proposed a new model (called Banking Event-driven Scenario-oriented Stress Testing) in order to overcome current drawbacks.

Fratzscher, Koenig and Lambert (2016) used a country panel for 50 advanced and emerging market economies to analyze how different factors affected aggregate bank stability and aggregate credit growth. They found out that higher capital buffers improved aggregate bank stability after the recent financial crisis, while strengthening of supervisory independence helped to reduce the decline in domestic credit and improved the stability of banks.

\section{Croatian Banking System}

At the end of the 1980s', banks in Croatia were mostly owned by the government. Big banks were doing business on state's behalf with purpose of giving loans to specific sectors of government's interest without adequate supervision and sufficient risk-management. Due to the fact that banks started to crumble during that period it was inevitable for them to turn to market, restructure and allow the transfer of assets from the public (government) sector to the private sector (Šubić, 2009).

During the end of 1990s', a huge number of small and medium sized banks were overly lending loans to their clients, which eventually caused them to default and consequently paved the way for foreign banks and foreign capital to promptly enter the market.

Nowadays, the number of credit institutions has been decreasing for the fifth consecutive year. The number decreased by two from the end of 2013, so there were altogether 33 credit institutions or 27 banks (huge drop in number of banks in comparison to 1997 when there had been 60 banks operating in the market), one savings bank and five housing savings banks operating in the Republic of Croatia at the end of 2014. Their assets stood at HRK 403 bn (roughly EUR $54 \mathrm{bn})^{1}$, with banks (including the savings bank) accounting for the dominant share or $98.1 \%$ of total assets of credit institutions. The housing savings banks accounted for the remaining $1.9 \%$ of total assets. Banks are mostly backed-up by foreign capital $(90.1 \%$ is foreign owned). Detailed ownership structure is presented in table 1.

1 Exchange rate of Croatian Kuna to Euro is approximately HRK/EUR 7,5 (in order to make it easier to understand the data presented). 
Table 1. Ownership structure of banks and their share in total bank assets

\begin{tabular}{|c|c|c|c|c|c|c|}
\hline & \multicolumn{2}{|c|}{ Dec. 2012} & \multicolumn{2}{|c|}{ Dec. 2013} & \multicolumn{2}{|c|}{ Dec. 2014} \\
\hline & $\begin{array}{l}\text { Number } \\
\text { of banks }\end{array}$ & Share & $\begin{array}{l}\text { Number } \\
\text { of banks }\end{array}$ & Share & $\begin{array}{l}\text { Number } \\
\text { of banks }\end{array}$ & Share \\
\hline Domestic ownership & 15 & 9.9 & 14 & 10.3 & 12 & 9.9 \\
\hline Domestic private ownership & 13 & 5.2 & 12 & 5.1 & 10 & 4.7 \\
\hline Domestic state ownership & 2 & 4.8 & 2 & 5.3 & 2 & 5.2 \\
\hline Foreign ownership & 16 & 90.1 & 16 & 89.7 & 16 & 90.1 \\
\hline Total & 31 & 100.0 & 30 & 100.0 & 28 & 100.0 \\
\hline
\end{tabular}

Source: Banks Bulletin 28, Croatian National Bank, August 2015

At the end of 2013, the largest number of banks, six of them, were owned by shareholders from Austria; their assets accounting for $59.2 \%$ of banks' total assets. This share had decreased from the end of 2013, when it stood at $60.1 \%$, due to noticeable reductions in the assets of three banks from the group (ranging from $4.1 \%$ to $6.0 \%$ ). They were followed by three banks in the majority ownership of Italian shareholders, one fewer than at the end of 2013 due to the merger of one bank from the group with a bank in majority owned by shareholders from Hungary. Nevertheless, the share of assets of these banks increased slightly, to $18.7 \%$, due to the noticeable rise in the assets of one bank from the group $(5.0 \%)$. Shareholders from Hungary, France, San Marino, Switzerland, Serbia and Turkey continued to have one bank each in their ownership, and for the first time, the Czech Republic joined the list in June 2014, when shareholders from that country became majority owners of a bank which had previously been in private domestic ownership.

Regardless of the fact that banks' share in the overall net assets of all financial intercessors for the last few years is gradually declining, banks still directly govern more than $3 / 4$ of financial means in Croatia. If we add assets of pension and various investing funds, governed by companies founded by banks, and assets of leasing companies owned by banks, we can conclude that banks directly and indirectly monitor more than $90 \%$ of financial means in Croatia (Jurman, 2009).

Croatian National Bank (CNB) classifies banks on small (S), middle (M) and big (B). The bank can satisfy for the criterion $\mathrm{S}$ if its assets are less than $1 \%$ of overall assets of all banks (Korinčić, 2014). The criterion $M$ is satisfied if the bank's assets are over 1\% and less than $5 \%$ regarding to overall assets of all of the banks which leads to conclusion that all the banks which assets rise over 5\% belong to the B category (Korinčić, 2014). Currently, the banking system is under the influence of big banks which account for $81.7 \%$ of domestic market.

At the end of 2014, total bank assets amounted to HRK 395.2bn (Figure 1). Banks' net loans totaled HRK 253.1 bn at the end of 2014, which is an annual decline of HRK 10.7bn or $4.5 \%$ effectively. The most substantial nominal increase at the annual level, of HRK 5.9bn, was recorded by banks' investments in securities which reached HRK 49.6bn. This raised the share of these investments to $12.6 \%$ of total assets, nearing its all-time high of $12.8 \%$ reported at the end of 2005 (Banks Bulletin, 2015). 


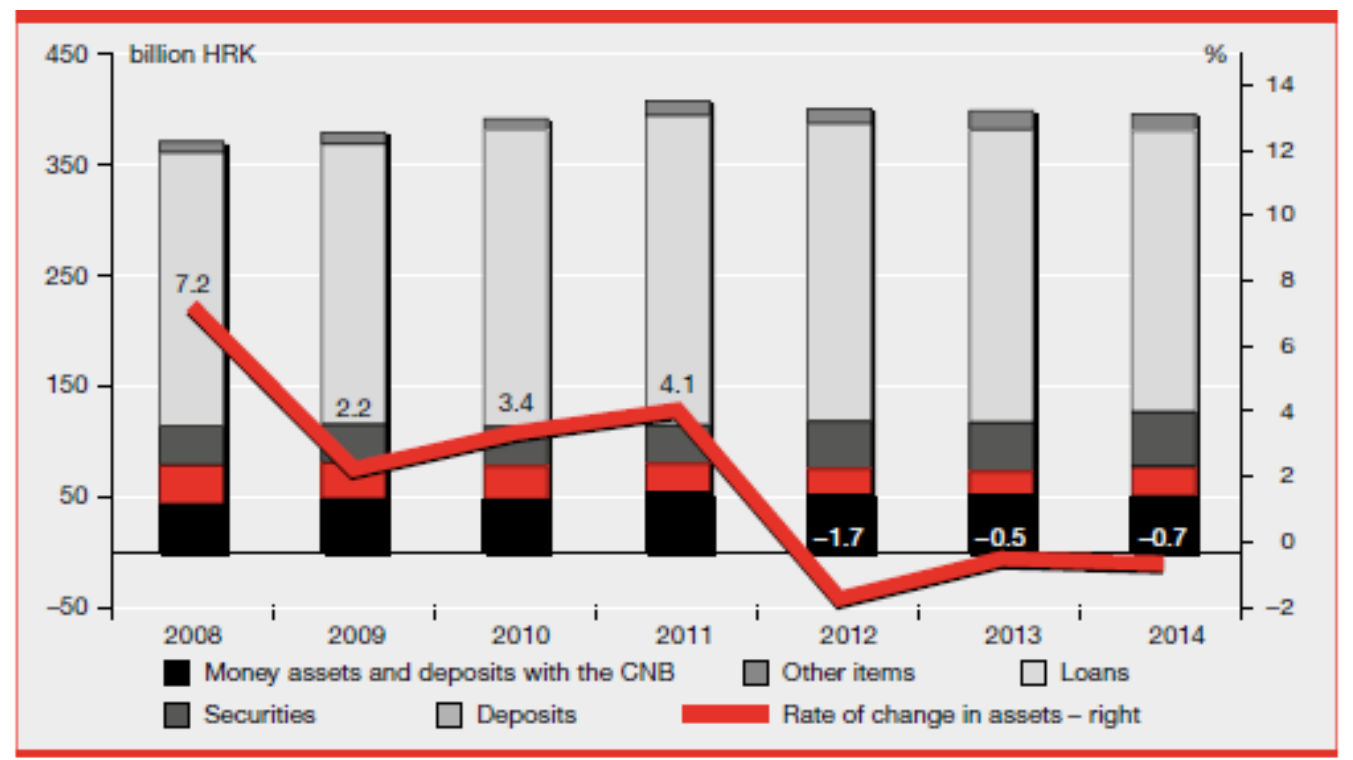

Figure 1. Structure of bank assets

Source: Banks Bulletin 28, Croatian National Bank, August 2015

At the end of 2014, total liabilities of banks stood at HRK $339.7 \mathrm{bn}$, down by $0.8 \%$ from the end of 2013 (Figure 2). If exchange rate effects are excluded, the annual rate of decrease was two times higher, standing at $1.6 \%$.The decrease in bank liabilities was for the most part influenced by banks continuing to deleverage, particularly vis-à-vis majority foreign owners. Total deposits stood at HRK 286.1bn at the end of 2014, up by $1.2 \%$ (only $0.3 \%$ if the exchange rate effect is excluded). This increase was due exclusively to an increase in deposits of domestic sectors, while deposits of non-residents, as a result of a fall in deposits of majority foreign owners, declined considerably reaching - 6.5\% at the end of 2014 (Banks Bulletin, 2015).

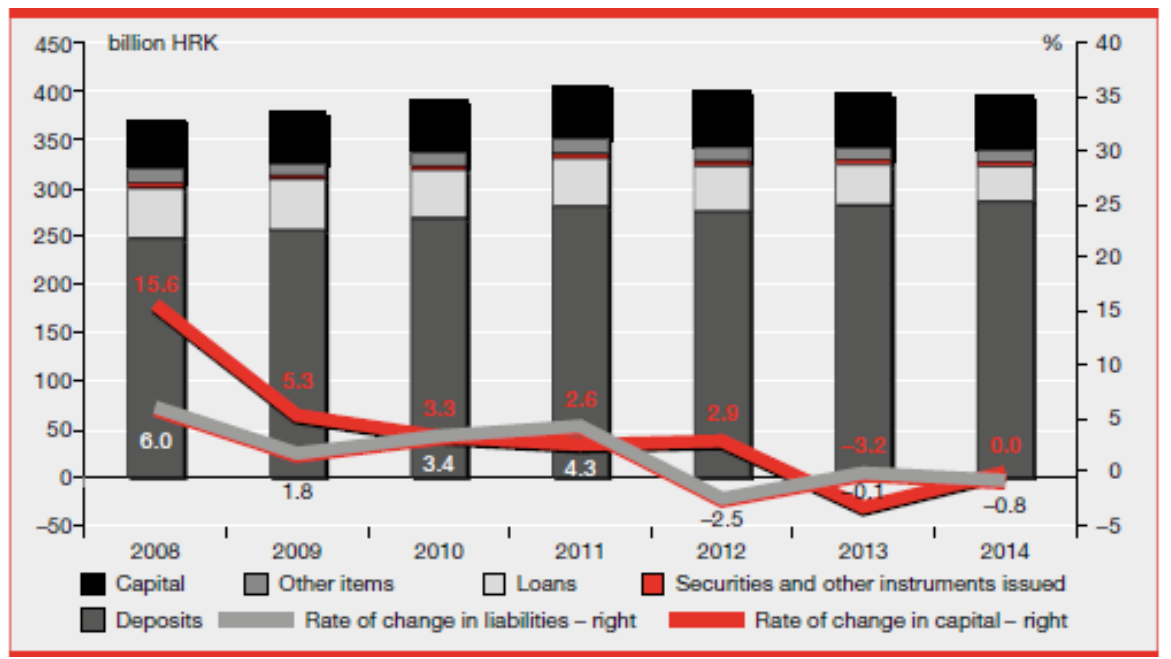

Figure 2. Structure of bank liabilities and capital

Source: Banks Bulletin 28, Croatian National Bank, August 2015 


\section{Ml Macrothink}

Return indicators in 2014 reached their lowest level since 1998 (Figure 3). The main reason for this is the increase in the level of provisioning expenses (Banks Bulletin, 2015). At the beginning of the crisis, banks were able to offset the growth of provisioning expenses through interest rate spread widening and stringent control of general expenses. Operating profitability increased and lower risk expenses additionally improved return indicators.

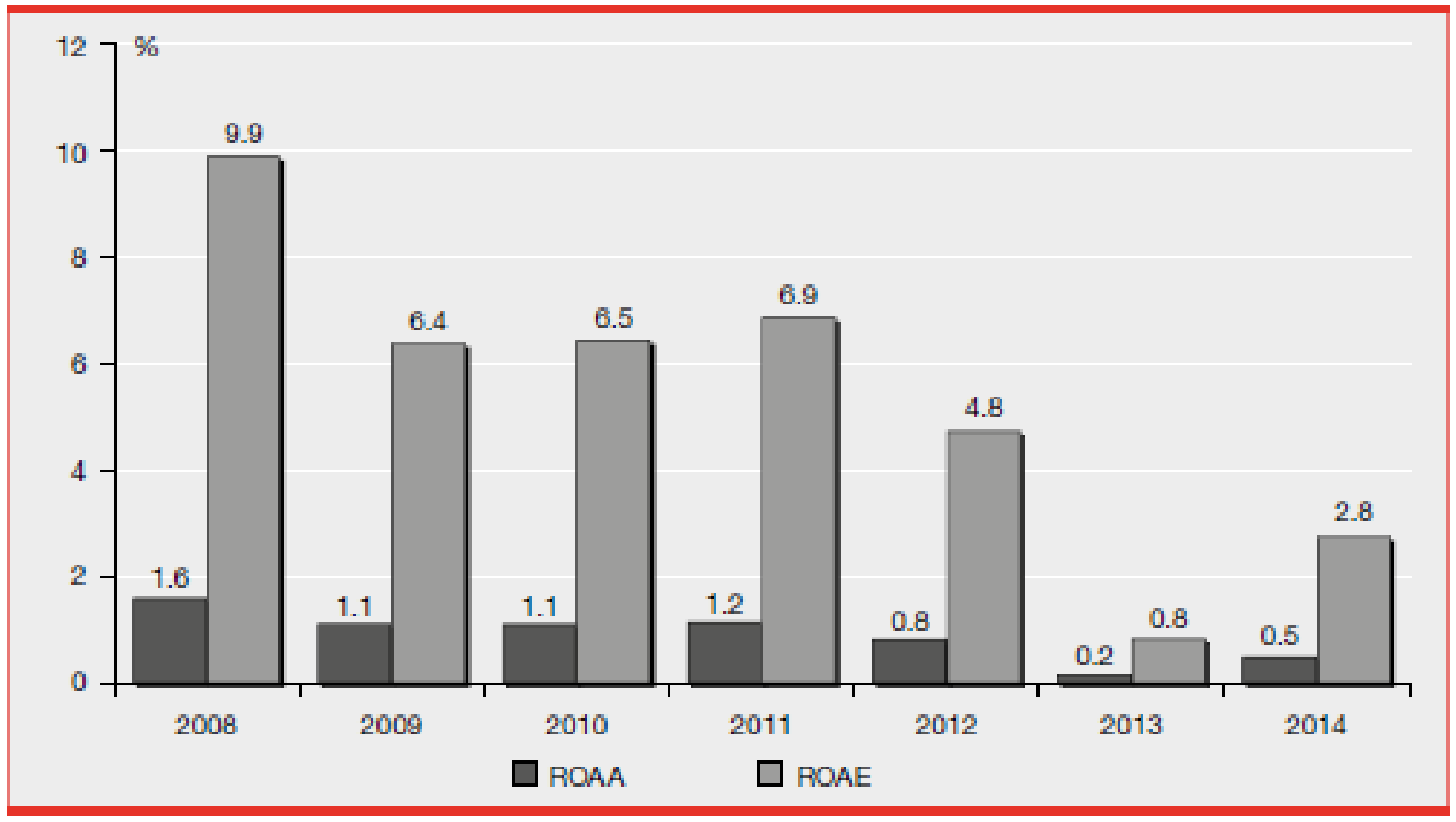

Figure 3. Bank return on average assets and return on average equity

Source: Banks Bulletin 28, Croatian National Bank, August 2015

\section{Stability and Resilience of the Banking System of Republic of Croatia}

The Croatian National Bank (CNB), the Ministry of finance and the Croatian Agency for Supervision of Financial Services share responsibility for stability of the banking system. Due to the high level of internationalization of the banking system, which is reflected in foreign ownership of the biggest banks, the CNB also cooperates with regulatory authorities and central banks of domicile countries of parent financial institutions.

Trying to increase banking system's resilience to shocks and decrease the process of risk-accumulation, the $\mathrm{CNB}$ implements various measures and instruments.

The most important measures and its effects on liquidity have been as follows (Bokan, Grgurić, Krznar, Lang, 2010):

- October 2008 - abolition of the marginal reserve requirement of 55\% on foreign borrowing by banks has created foreign exchange liquidity in the amount of 355 million EUR and 129 million USD; 
- December 2008 - decrease in banks' reserve requirement from $17 \%$ to $14 \%$ has released about 8.4 billion HRK;

- February 2009 - decrease in coverage of foreign currency liabilities by foreign exchange claims from $28.5 \%$ to $20 \%$ freed up to around 2.09 billion euro's of foreign currency liquidity.

Additional CNB's measures included:

- April 1st 2003 - the introduction of maximum permissible exposure of commercial banks at the end of the working day of $20 \%$ of its insurance assets;

- June 30th 2006 - increasing weights for the calculation of capital adequacy by 50 percentage points (the first increase by 25 percentage points);

- January 1st 2008 - a fourfold increase in the deposit insurance that now covers the amount to 400,000.00 HRK (approximately 56,000 euro's) per depositor and per bank.

The common goal of all of these measures was to eliminate fears that can cause deposits withdrawal and exchange rate depreciation via capital outflows. The CNB conducted a countercyclical policy between 2003 and 2008. This policy was characterized by strong accumulation of safety stocks of foreign currency liquidity and capital reserves and ensured stability of the financial system throughout the times of recent crisis. It is assumed that only those measures had released total liquidity of about EUR $3.5 \mathrm{bn}$.

When it comes to banking sector stability measurement, the capital adequacy ratio seems to be the most important indicator. Figure 4 shows that the capital adequacy increased since the very beginning of the global financial crisis of 2008. This indicates that Croatian banks maintained a high degree of stability amidst the crisis periods.

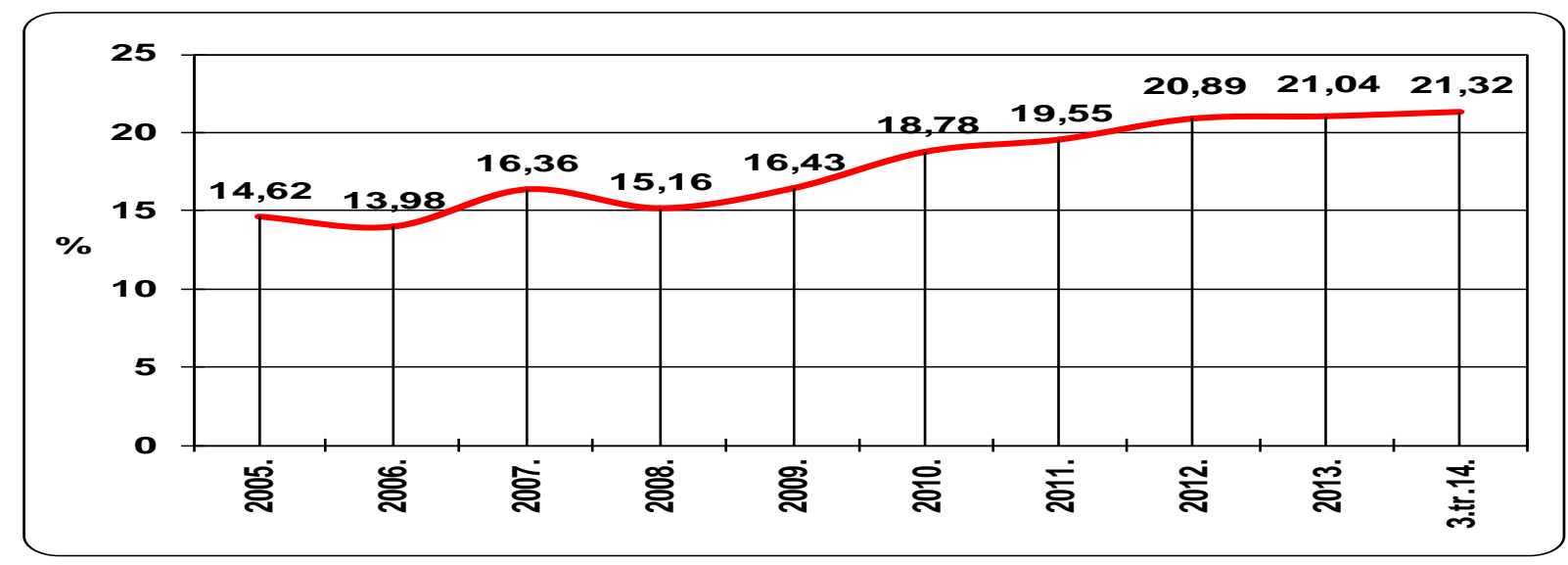

Figure 4. The capital adequacy ratio of banks' insurance assets (2005 - 2014)

Source: Banks Bulletin 28, Croatian National Bank, August 2015 


\section{Ml Macrothink}

Business and Economic Research

ISSN 2162-4860

2016, Vol. 6, No. 2

Foreign exchange reserves are also crucial indicator of financial sector stability. A decrease in international reserves is expected during the banking crisis as a result of protecting the exchange rate. However, the value of international reserves increased in the period 2008-2013 according to CNB. Resilience analyses carried out by the central bank showed high liquidity of the banking sector, especially high-quality primary liquidity (Banks Bulletin, 2015).

Various factors can trigger the instability in the banking system, but most often it is a combination of domestic macroeconomic instability and difficulties in business operations within individual banks. The fundamental macroeconomic causes of instability in the banking system are: low exchange rate, rate of GDP growth, high CPI inflation rate, large fluctuations that can threaten the viability of the exchange rate system, high and unstable interest rates, high foreign interest rates, increase of external debt, rapid financial liberalization, underdeveloped financial infrastructure, spillover effects of recession from other countries, etc.

The fall in GDP signals a decline in overall economic activity. High inflation biases the database for assessing credit risk, which accrues risks' portfolio and prevents the financial markets' development, especially in the long-term debt instruments segment (Miletić, 2009).

GDP had started falling in 2009 and continued to fall until 2015 when downfall finally stopped. During this period, the average annual rate of decline of GDP was $2.5 \%$, and according to Central Bureau of Statistics, the largest decline in GDP occurred in 2009, when GDP plummeted by $6.9 \%$. The fact that the GDP was declining had a negative impact on the quality of banking loan portfolio and the increase of outstanding receivables. The aforementioned drop in GDP reduced the level of development in Croatia compared to pre-crisis period, but also to the countries of the European Union.

Looking at the inflation rate on Figure 5 we can conclude that only the 2008 inflation rate was quite high when it amounted to $6.1 \%$, while the very next year the rate dropped to $2.4 \%$.

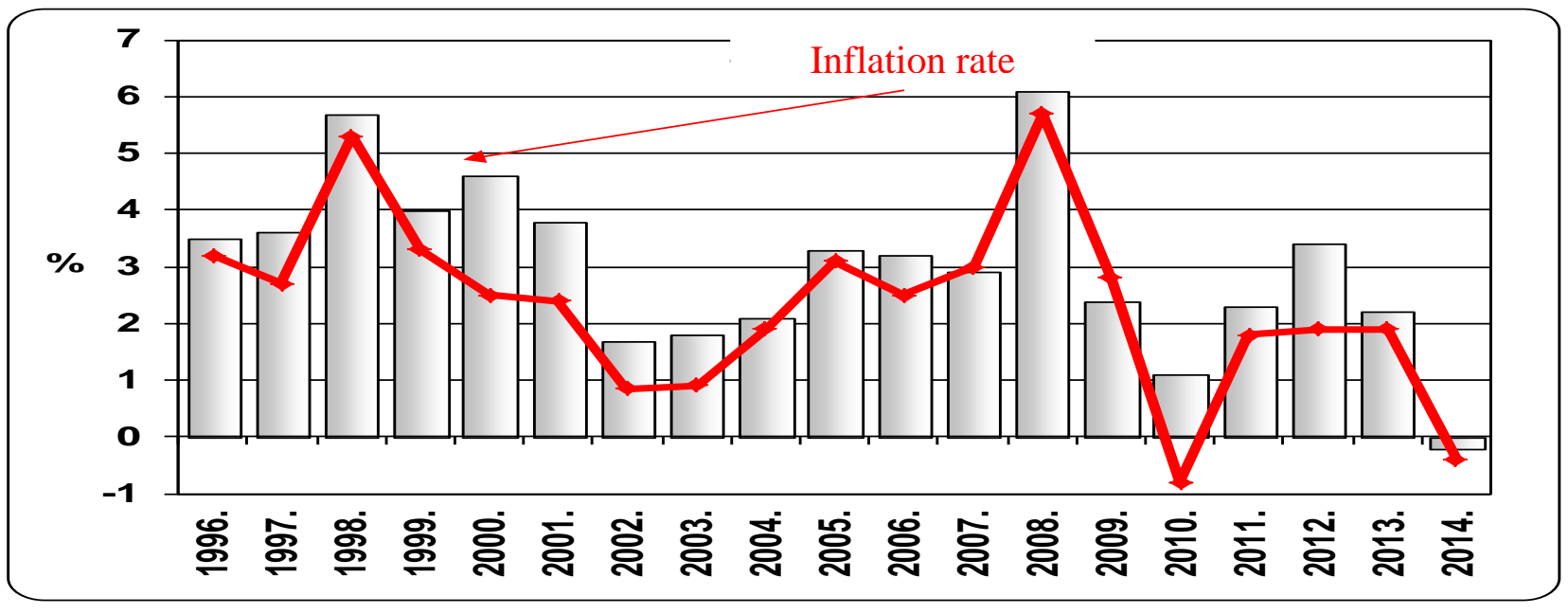

Figure 5. Inflation rates for the period 1996 - 2014

Source: Banks Bulletin 28, Croatian National Bank, August 2015 
In 2010 the inflation rate was $1.1 \%$ and after this period it began to rise. Yet in 2013 the inflation rate was the lowest since 2010 and it stood still at $2.2 \%$. The drastic decline in inflation can be seen in 2014 when the rate was $-0.4 \%$.

One of the important predictors of banking system stability is the level of foreign interest rates. High levels of interest rates can lead to an increase in volatility as foreign sources of lending become more expensive. Eurostat data shows a decrease in the levels of short-term interest rates in the European Union on the interbank market from 2008 to 2011, from 4.63\% to $0.81 \%$ in 2010 . Only in 2011 was there an increase of interest rates, which stopped at $1.39 \%$. Over the last couple of years, the European Central Bank continued its trend of lowering short-term interest rates in the interbank market, which at the end of 2014 stood at $0.05 \%$.

Examination of movements of domestic money market interest rates, according to the CNB shows that the interest rate in 2008 was exceptionally high $(5.77 \%)$, and recorded a drastic drop in the following years. At the end of 2014 domestic money market interest rate averaged at $0.28 \%$.

High levels of public and/or external debt may signal distortions in the financial system. Croatian public debt at the end of 2014 amounted to HRK 219.4 billion (approximately EUR 29 billion), or $67 \%$ of GDP. At the end of the first quarter of 2014, gross external debt of Croatia reached EUR 46.4 billion, or $108.1 \%$ of gross domestic product, the record high level.

Levels of credit expansion can signal forthcoming changes of stability of the banking system. Growth rate of loans issued in 2008 (in comparison to the previous year) amounted to $14 \%$, which indicated stable growth of retail banking. Right after 2008, loans issued significantly dropped and continued to fall in the following years. This was a strong signal of the disorder in the macroeconomic environment. Reduction of credit supply resulted in the strengthening of adverse selection and moral hazard problems. In 2009 loans issued to households fell by $3 \%$ in comparison to the previous year and have been continued to fall ever since.

Sensitivity of banking sector to possible disruptions is monitored by changes of movement of the deposits. Emergence of banking panic is signaled by drastic fall in the value of deposits in bank balance sheets, which could lead to a banking crisis. According to the Croatian National Bank data, this indicator had been growing until the end of 2011. Only in 2012 a slight drop was recorded, however, was not an indication of problems in the banking sector. Continuous monitoring of this indicator is crucial in getting early signals of potential banking sector instability.

\section{Stress Testing}

The analysis of Croatian banking system resilience conducted in 2014 by Croatian National Bank (Financial stability, 2014) showed that shock absorbers created in the past are still sufficient at the aggregate level, even in the case of appearance of (highly unlikely) unfavourable macroeconomic shocks. Results of this analysis (Financial stability, 2014) 
indicate that foreign exchange would remain stable, while aggregate bank income would deteriorate (by $1 \%$ in base scenario, by $23 \%$ in stress scenario respectively). At the same time, administrative expenses would remain stable. However, it is worth to notice that expected developments in the economy assumed by the stress test were based on the projections of the $\mathrm{CNB}$ and in the future may prove to be incorrect (e.g. stable financing conditions on foreign markets, stable growth of European economy etc.).

In comparison, regulatory agency of the European Union or the European Banking Authority conducted a stress test in 2014. The stress test included 123 banking groups across the EU and Norway (altogether 22 countries) with a total of EUR 28.000 bn of assets covering more than $70 \%$ of total EU banking assets (European Banking Authority, 2014). The objective was to assess the resilience of banks in the EU to adverse economic developments. It was based on common macroeconomic scenarios and a consistent methodology and was accompanied by unparalleled transparency into banks' balance sheets and the potential impact of severe but plausible shocks on them (European Banking Authority, 2014).

Overall the scenario tested under the 2014 EU - wide stress test saw EU banks experience EUR 261 bn of capital depletion mostly caused by credit losses (EUR 492 bn), which is only marginally offset by continued but diminished earnings. In the adverse scenario, 24 participating banks experienced a shortfall in the adverse scenario (leading to an aggregate maximum capital shortfall of EUR 24.6BN), including the 16 with a shortfall in the baseline scenario. Out of the 24 banks with a shortfall under the adverse scenario, 9 banks with an aggregate shortfall of EUR 9.4BN were from Italy, 3 banks with EUR 8.7BN of aggregate shortfall were from Greece and another 3 banks with EUR 2.4BN of aggregate shortfall from Cyprus (European Banking Authority, 2014).

As we pointed earlier, majority of Croatian banks are foreign-owned and do business as part of international bank groups. That is why results of stress testing for these six bank groups (Intesa Sanpaolo, UniCredit, Erste, Reiffeisen, Societe Generale, OTP bank respectively) are of utter importance for Croatian banking system. All of the aforementioned bank groups did well on stress testing.

\section{Conclusion}

Despite improved economic figures and expectations as well relatively more favourable international developments, risks to financial stability have remained high due to the considerable structural imbalances. Stress testing results have shown that domestic financial sector is capable of bearing highly unlikely but plausible shocks which could strongly undermine their business activities. From these we can conclude that current systematic regulatory measures of risk management are well calibrated and for the time being there is no need for adjustment of instruments in the direction of more stringent capital and/or liquidity requirements.

The continued favourable conditions in international financial markets are reducing the risks to Croatia's financial stability. However, a relatively slow economic recovery, coupled with the fast growth and high level of public debt, the large exposure of domestic sectors to 
changes in interest rates and the exchange rate and the resulting high sovereign risk premium are the main vulnerabilities of the domestic financial system.

\section{References}

Bokan, N., Grgurić, L., Krznar, I., \& Lang, M. (2010). Utjecaj financijske krize i reakcija monetarne politike u Hrvatskoj. Hrvatska narodna banka, Zagreb, 4-7. [Online] Available: http://www.hnb.hr/publikac/istrazivanja/i-025.pdf

Croatian National Bank (2015). Banks Bulletin 28, August 2015, [Online] Available at: http://www.hnb.hr/en/analyses-and-publications/regular-publications/banks-bulletin

Croatian National Bank (2014). Financial Stability 12, July 2014, [Online] Available:

http://old.hnb.hr/publikac/financijska\%20stabilnost/e-fs-12-2014.pdf

European Banking Authority (2014). Results of 2014 EU-wide stress test, [Online] Available at:http://www.eba.europa.eu/documents/10180/851779/2014\%20EU-wide\%20ST-aggregate $\% 20$ results.pdf

Fratzscher, M., Konig, P. J., \& Lambert, C. (2016). Credit provision and banking stability after the Great Financial Crisis: The role of bank regulation and the quality of governance. Journal of International Money \& Finance, 66, 113-135.

http://dx.doi.org/10.1016/j.jimonfin.2016.02.015

Gersl, A., Jakubik, P., Konecny, T., \& Seidler, J. (2013). Dynamic Stress Testing: The Framework for Assessing the Resilience of the Banking Sector Used by the Czech National Bank. Czech Journal of Economics \& Finance, 63(6), 505-536.

Hristev, V. (2014). Bank Stress-Testing Lessons from Central, Eastern and Southeastern European Countries. Economic Alternatives, 4, 92-109.

Hrvatska udruga banaka (2012). Poslovanje banaka 2011/2012: Povratak negativnih trendova uz iznimno visoku kapitalizaciju. HUB analize, 39/40, 5. [Online] Available at: http://www.arhivanalitika.hr/dat/hubanalize\%2039\%2040\%20aktivnost\%20profitabilnost.pdf

Hu, D., Yan, J., Zhao, L., \& Hua, Z. (2014). Ontology-based scenario modeling and analysis for bank stress testing. Decision Support Systems, 63, 81-94. http://dx.doi.org/10.1016/j.dss.2013.08.009

Jurman, A. (2009). Financijski potencijal hrvatskih banaka, obilježja i projekcija rasta. Ekonomska istraživanja. Sveučilište Jurja Dobrile, 60-80.

Korinčić, D. (2014). Financijski klub: Analiza hrvatskog bankarskog sektora. [Online] Available at: http://finance.hr/analiza-hrvatskog-bankarskog-sektora/

Melecky, M., \& Podpiera, A. M. (2012). Macroprudential Stress-Testing Practices of Central Banks in Central and Southeastern Europe: Comparison and Challenges Ahead. Emerging Markets Finance \& Trade, 48(4), 118-143. http://dx.doi.org/10.2753/REE1540-496X480407

Miletić, I. (2009). Makroekonomski i mikroekonomski uzroci nestabilnosti banaka. 
Ekonomska istraživanja. Sveučilište Jurja Dobrile, 47-59.

Schuermann, T. (2014). Stress Testing Banks. International Journal of Forecasting, 30(3), 717-728. http://dx.doi.org/10.1016/j.ijforecast.2013.10.003

Singh, S., \& Majumdar S. (2013). Macro Stress Testing for Indian Banking: VAR Approach. Indian Economic Review, 48(2), 275-296.

Šubić, R. (2009). Uloga stranih banaka u okrupnjavanju bankovne industrije. Ekonomski vjesnik, 22(2), 296-313.

Vallascas, F., \& Keasey, K. (2012). Bank Resilience to Systemic Shocks and the Stability of Banking Systems: Small Is Beautiful. Journal of International Money and Finance, 31(6), 1745-76. http://dx.doi.org/10.1016/j.jimonfin.2012.03.011

\section{Copyright Disclaimer}

Copyright for this article is retained by the author(s), with first publication rights granted to the journal.

This is an open-access article distributed under the terms and conditions of the Creative Commons Attribution license (http://creativecommons.org/licenses/by/3.0/). 